\title{
Collision and Collusion: contrasting representations of the translator-author relationship in two contemporary Francophone novels
}

According to Klaus Kaindl, "literature and film are never detached from society, but rather react to its developments, changes, upheavals with their own methods and devices" $(2014$, p. 4). It comes as no surprise, then, that translation becoming a somewhat commonplace activity in our global society coincides with "an increasing emergence of translation as a theme and translators and interpreters as protagonists in literature and film" (ibid., p. 3). The role of translators as objects of representation — rather than simply as agents of representation — in fiction has recently come to the fore of Translation Studies, and was discussed in Michael Cronin's book Translation Goes to the Movies (2008) which examines how translation as a narrative element is played out on screen, as well as in Dirk Delabastita and Rainier Grutman's special issue of Linguistica Antverpiensia "Fictionalising Translation and Lultilingualism" and in Kaindl and Karlheinz Spitzl's edited volume Transfiction: research into the reality of translation fiction (2014), both of which focus on the mise-en-fiction of translation and translators. A developing body of secondary literature now focusses on the interpenetration of the notions of translator and author in Francophone fiction (Bourse, 2010; Fülöp, 2014; Maussion, 2013; Plassard, 2010; Wecksteen, 2013) and on the porosity of the activity of writing and of translating (Constantinescu, 2009; Meschonnic, 1999; Ricœur, 2004). In works of fiction, the importance of the (in)famous theme of loss (whether symbolic, translational, or actual) is evident in the variety of book and film titles that explicitly refer to it: Eva Hoffman's Lost in Translation: life in a new language (1990), JeanPaul Fosset's Le Traducteur perd le Nord (2008); Olivier Balazuc's Le Labyrinthe du traducteur (2010); and famously Sofia Coppola's film Lost in Translation (2003). Another common theme emerging from transfiction (that is, "the introduction and (increased) use of translation-related phenomenon in fiction" [Kaindl, 2014, p. 4]) is that of translation as a relationship-often binding a translator to the author they are translating. This is particularly evident in French and 
Francophone fiction, as the following titles illustrate: Jacques Poulin's La Traduction est une histoire d'amour (2006); Claude Bleton's Les Nègres du traducteur (2008); Brice Matthieussent's Vengeance du traducteur (2009); Jacques Gélat's Le Traducteur amoureux (2010), to name but a few ${ }^{1}$.

The present article examines two novels in particular, French writer Brice Matthieussent's 2009 Vengeance du Traducteur and Québécois Jacques Poulin's 2006 La Traduction est une histoire d'amour. Among all the fictional texts incorporating translators and translation, the choice of these two particular novels lies in the fact that they present apparently contradictory viewpoints on the role of the translator and translation through their distinctive use of both metaphors and meta-discourse on translation, in addition to opening up a dialogue between France and Quebec on this topic. Specifically, Matthieussent's novel is a revenge indeed, a postmodern tour de force where the notions of original, translation, source and target texts, author and translator, are blurred to the point of becoming irrelevant, shedding a whole new light on the concepts of faithfulness and creativity, and redefining typographical and cultural spaces. Presented as a translation by its narrator, Vengeance $d u$ Traducteur is a discussion about translation, a metaphorical and symbolical—yet playful and entertaining — deconstruction of the author-translator relationship, which creatively and cynically dissects power relations in the translation process, and questions the validity of the notions of author and translator, pointing out their absurdity. Poulin's novel approaches the author-translator relationship more traditionally, portraying a young woman, Marine, the first-person narrator, planning to meet Jack Waterman, an author she admires, and become his translator. Though she is successful in this, few scenes focus on translation proper; instead the writer and translator must determine the owner

\footnotetext{
${ }^{1}$ There are a number of studies considering the figure of the translator in literature which can be consulted for examinations of other texts. For Quebec literature, see in particular Godbout (2010) and Simeoni (2004). For French literature, see Bourse (2010), Plassard (2010) and Wecksteen (2013). .
} 
of an abandoned kitten, using a cryptic note on its collar. To do so, they must find the right words to complete the clue, and also determine what these words truly mean. The cooperative, symbiotic connexion between the two outside their working relationship becomes a metaphor in itself for the process of translation; this in turn focuses a spotlight on the work of translating which is gradually relegated to the background of this novel whose title announces it as central. Nonetheless, despite these already substantial differences, we will see that there are also similarities, stemming perhaps from the fact that, as Godbout notes, the question of the translator's identity serves as a background to all these representations: "Qui est [le traducteur]? Sa propre identité devient-elle érodée ou disoloquée du fait qu'il enfile, pour ainsi dire, les habits d'un autre en le traduisant? Le traducteur fictif souffrirait-il de ne pas être reconnu comme un intellectuel de plein droit? Et d'ailleurs, qu'est-ce un intellectuel? C'est toute la problématique du statut du traducteur dans la république des lettres, de sa reconnaissance professionnelle notamment, qui est ici mise en relief" (Godbout, 2010, p. 168).

The emergence of translation as a theme is perhaps due to its potential for staging intrigue or mystery through issues relating to the encryption and decryption of messages, or because of translators/interpreters' testimonial roles, which means they have access to potentially confidential information, or in the case of interpreters who have to be physically present where the action takes place. Translation and translators appear to lend themselves well to taking centre stage in crime fiction: the conflicts of interests, combined with the necessary cooperation between authors and translators are often the catalyst of a relationship that has the potential to be constructive and destructive in equal measures. While a translator may sometimes collaborate, cooperate or collude with an author in order to produce a translation of a text, their two paths are socially inextricable and yet appear to be on a collision course. In the words of Jonathan Rée, "translators have a habit of feeling rather sorry for themselves. The problem is not just that they are badly paid, though they often are; nor that their contribution to culture is constantly slighted or overlooked, though it usually is. What depresses them, above all, is the question of their 
creative identity" (2001, p. 223). Whether or not we agree with Rée, this widespread feeling of being disregarded sets the stage and poses the question of how translators in fiction deal with the question of their creative identity.

Both Matthieussent's and Poulin's novels portray important features of the whodunit genre, where the complex interplay between authors and translators allows readers to get an insight into the varying fortunes of their relationship. Beginning with the summary on the back cover of Matthieussent's novel Vengeance du Traducteur we see its description as a "roman" is immediately undermined by the presentation of the text: in the first half of the book, the pages offer more blank space than text, and readers are only provided translator's notes, which sit underneath a black line - a feature not usually associated with novels - that traditionally separates the author's space from the translator's. ${ }^{2}$ The book opens with a rather ambiguous statement:

* Je loge ici sous cette fine barre noire. Voici mon lieu, mon séjour, ma tanière. Les murs sont peints en blanc, puis couverts de nombreuses lignes de minces caractères noirs, comme une frise irrégulière, un papier peint changeant. Bienvenue à toi, cher lecteur, franchis donc le seuil de mon antre. Ce n'est pas aussi spacieux que chez mon voisin d'au-dessus [...]. Je sais que c'est lui que tu venais voir, et tu tombes sur moi. Il faudra t'en accommoder. Dans ce modeste espace je joue des coudes. J'empile ces lignes pour que ma cave ne soit pas un cercueil, ma soute un tombeau. (Matthieussent, 2009, p. 13)

It is not clear at this point whether this first person refers to "a human consciousness [or] to the text itself” (Fülöp, 2014, p. 55), and this lays the foundation for an examination of identity which

\footnotetext{
${ }^{2}$ The use of footnotes for fictional purposes is not a new one, as Gérard Genette points out (1987, pp. 293-315). Also see Fülöp (2014, p. 64).
} 
always poses itself as a central question in narratives about translation (Kaindl, 2014, p. 8). After a few pages of ontological uncertainty, readers find that the novel is actually narrated by a French translator-narrator, who could be Matthieussent's alter ego ${ }^{3}$ and claims to be translating an American novel entitled Translator's Revenge, ${ }^{4}$ in which the protagonist is an American translator named David Grey currently translating into English a French novel entitled (N.d.T.) written by fictional author Abel Prote. ${ }^{5}$

The translator's notes consist of a mixture of actual translator's notes in which the translator explains a particular translation issue he has encountered-often loaded with symbolism — but he also spends a lot of time talking about his own situation, his own mindset, his own condition. He explains straight away that he has a somewhat conflictual relationship with his upstairs neighbour: the top of the page belongs to the author, it is a space where the translator does not exist, a space where the translator is invisible. This relationship becomes the object of a "dramatisation romanesque" (Maussion, 2013, p. 3): the translator lives at the bottom of the page, underneath the dividing line which is like a (trap) door between his "cave" ("D'habitude, je ne reçois personne, je reste invisible et muet, assigné à residence exiguë, relégué sous terre”,

\footnotetext{
${ }^{3}$ Matthieussent is a prolific translator of American novels by authors such as Bret Easton Ellis, Charles Bukowski and John Fante — so Matthieussent is in that respect used to switching between his author and translator hats.

${ }^{4}$ We note that the French title, Vengeance du Traducteur, echoes the title of Roland Barthes' famous essay 'La mort de l'auteur" (and by extension Michel Foucault's “Qu'est-ce qu'un auteur?")—and in fact provides a suspect for the crime-while the American title appears to be a reference to Lawrence Venuti's monograph The Translator's Invisibility. Matthieussent's novel displays a rich intertextuality, and addresses, under the guise of fiction, issues of authorship and invisibility discussed by both Barthes and Venuti.

${ }^{5}$ It is safe to assume that any fictional figure named Abel is going to be killed by their evil twin, whilst the name Prote again is yet another reference to the chameleon-like, polymorph qualities of the writer and invites questions of identity (the prote is also the head proof-reader in a printing shop). Interestingly, Prote's name also echoes the title of a collection recently co-edited and published by Erika Fülöp and Adrienne Angelo, Protean Selves. FirstPerson Voices in Twenty-First-Century French and Francophone Narratives (2014).
} 
Matthieussent, 2009, p. 13), and the luxury apartment of his upstairs neighbour. The narrator explains that he usually stays invisible, and in silence, underground, like a "fantôme obéissant et fidèle" (ibid.) which echoes relatively recent theoretical discussions in Translation Studies about the invisibility of translators, but also provides a motive for the predictable — and in fact, it has to be said, entirely expected-demise of the author. The narrator-translator knows he has a voice, but that his voice cannot—should not—be heard, thus echoing what Lawrence Venuti describes as 'self-annihilation' (Venuti, 1995, p. 8) and confining the translator to a "shadowy existence" (ibid.) inextricably connected to the omnipresence of the authorial figure, "comme l'ombre demeure rivée au corps" (Matthieussent, 2009, p. 14). Having established that the master lives upstairs - both typographically but also of course symbolically — and the quiet and obedient servant downstairs, the narrator-translator is going to try and overturn the situation. The transgressions ${ }^{6}$ are small at first — the narrator-translator edits out all the adjectives and adverbs:

L'estimé lecteur aura remarqué que depuis le début du présent chapitre aucun adjectif ne vient plus encombrer la prose pataude de mon auteur. Il ne s'agit pas d'une décision de ce dernier, mais [...] d'une sorte d'oukase décrété par moi. Je sais bien que pareilles suppressions sont peu défendables du point de vue déontologique [...] mais, cher lecteur, reconnais qu'après ce robuste élagage, sa prose gagne en élégance et en fluidité. Finies ces lourdeurs insupportables, ces agglutinations d'adjectifs dont on ne voyait pas la fin ! [...] Et si maintenant je sucrais les adverbes? (Nuisance du Taraudeur) (Matthieussent, 2009, p. 33)

He proceeds to remove all the comparisons, and eventually deletes whole paragraphs, replacing them with new ones of his own making, gradually giving more credence to the old adage traduttore, traditore, though he justifies himself with claims of being a better writer than the

\footnotetext{
${ }^{6}$ Plassard (2010, p. 63) provides further insight into the nature and variety of these transgressions.
} 
author. The novel culminates in a metalepsis, with the narrator-translator breaking the ceiling that is the footnote separator, and thus staging a revenge that is both "personal and textual" (Maussion, 2013, p. 3; our translation), and claiming authorial prerogatives for himself in the process: ${ }^{7}$

C'est fait. À dix mille mètres au-dessus de la houle atlantique, profitant de la boule de cristal ou de ce primitif écran radar où nage la nuée d'astérisques pâles lentement sillonnée par un couple d'étoiles clignotantes vert et rouge, grâce au bol divinatoire où se croisent deux trajectoires opposées sous les yeux incrédules de David, je fais le pas et franchis la barre pour m'envoler à mon tour. (Matthieussent, 2009, p. 193)

The narrator-translator had until now assumed different roles, from that of craftsman, artisan, slave, censor, archeologist, thief... ${ }^{8}$ as Matthieussent exploits all the analogies associated with translators, as testimony to his polymorph nature, and prefiguring his ability to stand in for the author. ${ }^{9}$ The narrator-translator goes on to meet the rather puzzled and confused characters of the very novel he is translating. The novel ends with the narrator-translator confronting Abel Prote and threatening to erase him from existence by editing his name out of the whole novel, right before Abel himself accidentally hits the "delete" key and disappears into oblivion:

\footnotetext{
${ }^{7}$ Matthieussent (cited in Wecksteen, 2013, p. 63) himself expressed the view that the translator is an "écrivant" (to recycle Barthes' term) rather than un “écrivain”. The novel challenges this notion.

${ }^{8}$ A more comprehensive list is provided by Bourse (2010, p. 5).

${ }^{9}$ Incidentally, Bourse (2010, p. 4) refers to the failure of translation to provide a definition for itself that does not rely on analogies as a "catastrophe métaphorique". This problem of self-definition is evident from the titles of the articles that examine Matthieussent's Vengeance du Traducteur. See in particular Plassard (2010); Wecksteen (2013); Maussion (2013).
} 
Je sélectionne les mots Abel Prote dans tout le texte et mon index s'abaisse vers la touche Suppr du clavier, quand Prote bondit brusquement du canapé avec une souplesse que je ne lui soupçonnais pas. Puis sa tête heurte violemment mon ordinateur et tout à coup je me retrouve seul dans la pièce. Le corps massif de mon assaillant, un bref instant vautré au travers du mien, a disparu. Soudain, je respire. Ce n'est pas moi qui ai enfoncé la touche Suppr, mais le front de Prote, alors que cet idiot voulait à tout prix empêcher mon doigt de rejoindre le petit rectangle noir. (Matthieussent, 2009, p. 302)

In the epilogue, in one final twist, we learn that the translation is going to be published in its own right, as an original, and is itself going to be translated.

In Vengeance du Traducteur, the destruction of the author is first and foremost textualthe narrator-translator gradually brings more and more changes to the source-text he is supposedly translating, first on the scale of single words and then to whole paragraphs, as we have discussed above. This challenge to fidelity is echoed typographically, visually, on the page itself, as the footnote separator is pushed up a little more with each page, as the narrator-translator appropriates the physical territory of the author, in what Erika Fülöp, drawing on Gilles Deleuze and Félix Guattari's work, describes as a "deterritorialization" (2014, p. 59), which is defined as “le mouvement par lequel ‘on’ quitte le territoire. C'est l'opération de la ligne de fuite” (Deleuze \& Guattari, 1981, p. 634). ${ }^{10}$ The process is staged by Matthieussent in a way that is as playful as it is violent: the interlocking of the different narrative layers means that traditional boundaries between author and character, narrator and character, translator and author are challenged, until they become altogether meaningless. And yet this violence is not anomic-it is cultivated, structured, has an internal logic, and abounds in intertextual references — which the lack of space prevents us from analyzing in greater depth here. The relationship between translator and author is explicitly portrayed in Vengeance du Traducteur as an Oedipal one; the author has fathered a

\footnotetext{
${ }^{10}$ On the notion of deterritorialization, also see Kaindl (2014, pp. 2-3).
} 
text, and has the upper hand on the translator: “Abel Prote veut profiter de sa paternité littéraire pour contraindre David à des aménagements en forme de déménagement: (N.d.T.) a beau avoir Paris pour cadre, Prote voudrait que Grey transpose le roman à New York” (Matthieussent, 2009, p. 63). The higher status given to the author manifests itself in different ways in Vengeance du Traducteur. First, the author of the text is named Abel - the first name alphabetically, while Prote means "first" in Greek. When the narrator-translator finally breaks free, he becomes a "géniteur textuel" (Matthieussent, 2009, p. 229). The sexually violent nature of translation demonstrated here is discussed by Lori Chamberlain in her paper on "Gender and the Metaphorics of Translation" where she states that "what the translator claims for 'himself' is precisely the right of paternity; ${ }^{11}$ he claims a phallus because this is the only way, in a patriarchal code, to claim legitimacy for the text" (1988, p. 466). In Vengeance du Traducteur, authors and translators compete to be the alpha male, the first, the original, the one who creates, the father. Translation, precisely because of the dialectic role it has with the source-text, is a threat to it: "what the original risks losing [...] is its phallus, the sign of paternity, authority and originality" (ibid.). The translator has to kill the text's father for his existence to be acknowledged, and to an extent, fulfilled.

While we have seen that the author's staged castration is at first textual and typographical, the attempt to get rid of the author culminates in the ironic self-destruction of Abel, leaving the narrator-translator just short of being a murderer, or a "traductueur" (Maussion, 2013, p. 58; our italics). In the meantime, the only female character of the novel, Doris, the love interest and object of desire, "la belle parleuse, l'incontinente verbale" (Matthieussent, 2009, p. 234), becomes infatuated with the narrator-translator but only after entertaining relationships with Abel and David first. Through Doris, David Grey and the narrator-translator take control of the text, symbolically and physically. Again this relationship can be understood on different levels, as a

\footnotetext{
${ }^{11}$ The notion of paternity in Matthieussent's novel is briefly discussed by Wecksteen (2013, p. 56).
} 
part of fiction, but also as a metaphor of the symbiotic relationship between the translator and the text - a metaphor that is made explicit in a scene that describes Doris and David's lovemaking, where the "corps imbriqués" are compared to the "textes emboités" (Matthieussent, 2009, p. 282), painting Doris as a "belle infidèle" and adding credence to Chamberlain's thesis that the sexualization of translation always favors the masculine:

Clearly, the meaning of the word "fidelity" in the context of translation changes according to the purpose translation is seen to serve in a larger aesthetic or cultural context. In its gendered version, fidelity sometimes defines the (female) translation's relation to the original, particularly to the original's author (male), deposed and replaced by the author (male) of the translation. (Chamberlain, 1988, p. 461)

The love/oedipal triangle - and then quadrangle once the narrator-translator starts interacting with the characters in the story he is translating - in Vengeance du Traducteur is an exact fictionalization of the male-centred phenomenon Chamberlain describes. To use Gavronsky's imagery (1977, p. 55), the translator, David Grey, is constructed as a child of the author-fathercreator, while the text, embodied in the narrative by Doris, becomes the object of desire, which has initially been completely forged by the phallus-pen of the paternal figure. The only way for David - and later the narrator-translator - to free himself from the authority of the father is to make the text-Doris-his: "symbiosis has occurred for the translator-the act has been performed and, as the Tao declares, out of two, one" (Gavronsky, 1977, p. 56). The translators in Vengeance du Traducteur all in some ways (textual, symbolic, physical) manage to usurp authorial prerogatives, but the power always lies with men.

On the other hand, Jacques Poulin's novels evoke a very different atmosphere than Vengeance - they take place in small cities or on semi-deserted islands, and there is not a computer in sight, since everyone writes longhand. Communication between author and 
translator takes place face to face or via letter, email is not an option. The traditional, patriarchal male-female power (im)balance that is at the crux of Chamberlain's previously mentioned analysis of the use of gendered metaphors to describe both translations and translators seems at first glance to be again performed — and reinforced by an age difference-in Poulin's $L a$ Traduction est une histoire d'amour. However, a closer examination of this novel, with its focus on the fictional Québécois author Jack Waterman and his young, female translator Marine, and two others, Les Grandes marées and L'anglais n'est pas une langue magique by the same writer where translation plays a role, show that the relationship is more complicated than this. In their interactions in writing and life - the supposed plot of the novel requires Waterman and Marine to collaborate to find the owner of a lost kitten - the two characters seem to alternate the role of powerholder in the relationship. Perhaps it is the ongoing shifting between powerful and weak that allows them to attain a naive state of restitution or compensation, to use Steiner's terms.

Poulin is most well-known for his road-trip novel Volkswagen Blues, published in 1984, and the writer-character Jack Waterman (a pseudonym, though even his brother calls him by this name) we meet in La Traduction est une histoire d'amour is the brother of the protagonist in the earlier novel. Waterman, and a third brother who makes his living using words and literature by reading to people, are also present in a third novel entitled L'Anglais n'est pas une langue magique, published in 2009, a kind of sequel to La Traduction. While language and words are central to La Traduction and L'Anglais, Poulin's interest in translation dates from much earlier in his writing career, appearing first in 1978's Les Grandes marées, where a translator of newspaper comics is the main character around which all others revolve. Like Matthieussent, Poulin began his career as a translator, for the Canadian federal government, but has made his living as a writer since the mid-1970s. Along with an interest in language and translation, Poulin's fascination for the history and (linguistic) shaping of North America, particularly during 
the period of migration westward along the Oregon Trail is more than a backdrop to each of these novels. $^{12}$

As in the case of Vengeance du traducteur, La Traduction est une histoire d'amour is narrated by the translator, however in this case, she shares a very different relationship with the author, whom she always refers to as monsieur Waterman, even at the novel's conclusion when they seem to be sharing an intimate, though non-sexual, relationship ("Les histoires de sexe, on ne s'en occupait pas, monsieur Waterman et moi" [Poulin, 2006, p. 75]). Furthermore, without ever being lovers, they mimic a family relationship in becoming foster parents to a recently suicidal teenage girl named Limoilou. The closeness of their connection is evident from the novel's first pages, in their sharing of living space — at least on the weekends — and in Marine's lack of inhibition or desire to be provocative when swimming naked in front of Waterman. Throughout the novel, their relationship is easy to read as a romance, its own very particular type of intimate partnership, almost set up on a blind date by a stranger in France who gives Marine Waterman's book whose back cover indicates “il était question de la Piste de l'Oregon” (ibid., p. 19). Having visited this area herself, Marine is so intrigued by this cover matter that she first has the idea of translating its author without ever reading a word of the novel proper ${ }^{13}$. When she is back in her home of Quebec City after a long absence for study, a chance encounter between the author and translator in the cemetery where Marine's mother and sister are buried sets in motion the ultimate meeting in the neighbouring library where the young translator will offer her sample translation to Waterman. The scene where the text is offered, can indeed be read like the beginning of a romantic relationship, where, attracted by the older author's text, the young translator seeks to pique his interest by offering him a translation of that same text. When he asks

\footnotetext{
${ }^{12}$ For development on the role of writing in Poulin's early novels see Giacomo Bonsignore (1985).

${ }^{13}$ The textual seduction of the translator in this novel can be compared to that in Brossard's Le désert mauve.

“Maude Laures s'était laissé séduire, ravaler par sa lecture” (p. 59).
} 
what she is translating, Marine is tongue-tied and embarrassed: "Les mots se bloquent dans ma gorge. Incapable de répondre, je n'ai pas d'autre choix que de déplacer mon cahier pour qu'il voie son livre. [...] [I]l demeure d'un calme absolu. [...] Je suis séduite si vous voulez le savoir, mais il n'est pas question de le montrer" (ibid., p. 27). The translated text expertly hits its mark and gains Waterman's approval who, after reading it, exclaims "La petite musique est là !" (ibid.). The reaction of each character sharpens the sense that the translator-author relationship mirrors a romantic one, and the author is so impressed by Marine's work that he offers her, rent free, access to his isolated cottage where she can work alone and uninterrupted. Believing it to be her lucky day, Marine accepts the offer but with a somewhat ironic catch, "[à] condition que je paie mon loyer et que je le rembourse de toutes ses dépenses. Je voulais garder mon indépendance" (ibid., p. 28), even though she has told him repeatedly she has no money.

Just as Matthieussent's narrator-translator struggles to liberate himself from domination by Prote and his text, the notion of independence is one that Marine returns to often, though much less violently, though occasionally using the same strategy as Matthieussent, and speaking directly to the reader, when she says for example: "Pour afficher ma liberté, si vous voulez savoir" (ibid., p. 37, our italics). The importance of freedom — in life and in translation-is reiterated in a number of ways: "Les seules règles que j'accepte sont les règles de grammaire” (ibid., p. 14); “Pour préserver ma liberté, je n'avais pas de portable" (ibid., p. 43); "Je ne veux être la fidèle compagne de personne" (ibid., p. 47). The fear of losing her independence is such a prominent concern in her life that Marine even speaks about it to the willow trees near her cottage-_ "je leur expliquais que ma vie, à moi aussi, devenait compliquée, que je perdais mon indépendance, et que je me sentais vulnérable comme eux" (ibid., p. 95). Nonetheless, she longs for the personal connection with Waterman: after suffering a concussion after falling into the pond, she reacts with an understated kind of desire to the author's attention, wishing “qu'il s'occupe de moi , si vous voulez le savoir" (ibid., p. 115). And when he does look after her, putting a blanket around her, rubbing her body to warm her up, her reaction is very positive: "J'aurais voulu que ça ne 
s'arrête jamais et, pour un peu, je me serais mise à ronronner" (ibid., p. 116), though the word ronronner" brings us closer to a physical than an intellectual or even emotional kind of pleasure.

Despite this desire for connection, on other occasions, she extends the application of her personal freedom so far as to even go against the accepted or preferred usage of words. For example, in the above cited remark about not having a mobile phone, she explains her preference for the word portable (as is used in France) as opposed to the more Canadian cellulaire "qui pour (elle) évoque la prison" (ibid., p. 43). Occasionally, her motivation is less explicit, but even more personal and forceful: "Je m'installais avec [le livre] dans la chaise berçante-il faut dire 'berceuse' mais pour certains mots chargés d'émotivité je fais une entorse aux recommandations du Petit Robert" (ibid., p. 36). Whilst some would see her position as a translator as feeding into this vulnerability and loss of liberty, Marine, for her part, sees it at least partly as a way to affirm her independence, as both she and Waterman agree with Borges who said "Le métier de traducteur [...] est peut-être plus subtil que celui d'écrivain. [...] La traduction est une étape plus avancée" (ibid., p. 23, our italics), meaning that this profession requires more than slavish obedience to a pre-existing text, or, by extension and the novel's subtext, to an author or a set of grammar rules.

This apparent superiority of the translator can also be found in the physical vitality —or lack thereof - in both the author and translator characters. In his earlier novel featuring a translator, Les Grandes marées, written nearly thirty years before La Traduction, Poulin illustrates a rapid decline in the health of the translator over the course of one summer. Like Marine, this translator is an individual who prefers dictionaries, words, and solitude, to the point it seems of suffering physically as he is forced into greater and greater interaction with a growing group of people on an island that was deserted when it was offered to him by his boss. On the other hand, though she worries about losing her independence, Marine is never portrayed as physically weak. She is strong enough to swim in the icy waters of the cottage's pond to keep it 
clear of invasive algae, and, when she decides to do so, can be very seductive, explaining "C'est une arme secrète que j'utilise [...] mais seulement en cas d'urgence" (ibid., p. 84).

Poulin changes strategies between L'Anglais n'est pas une langue magique and La Traduction est une histoire d'amour, where the writer becomes weaker and the translator stronger. In the later novel, Waterman, writing what is expected to be his final book, suffers from a heart condition and struggles to write standing up because his painful back does not allow him to remain seated for long. Not only is "monsieur Waterman [...] maigre et fatigué [... mais il] avait déjà fait un infarctus. De temps en temps son cœur s'arrêtait quelques secondes... et repartait" (ibid., p. 54) but, in Marine's opinion, "il ne tenait pas beaucoup à la vie depuis son dernier livre" (ibid., p. 76). If we follow this logic farther still to the novel's sequel, L'Anglais n'est pas une langue magique, we see that Waterman and Marine are still in a relationship“l'amie de mon frère exerçait le métier de traductrice" (Poulin, 2009, p. 29), explains the writer's brother, Francis. But in knowing his brother's increasing difficulties in writing —-"en ce moment c'est devenu une demie page le matin. Les mots viennent à petites gouttes" (ibid., p. 115), Francis, interpreting an interview with Ernest Hemingway, leads us to believe that this struggle is related to his personal relationship with Marine. He muses, "Le célèbre écrivain avait laissé entendre qu'il s'abstenait de faire l'amour chaque fois qu'il avait à décrire des rapports intimes dans un roman ou une nouvelle. Ce qui revenait à dire que la libido et l'écriture provenaient de la même source" (Poulin, 2006, p. 116). Perhaps as a result of this reality, interestingly, it is not the translator who usurps the place of the writer in the literary world, but this same Francis, the little brother of the writer, who takes his place in the real-world life of the translator. Interacting more and more with Marine, as he comes to the chalet to read to Limoilou, Francis desires a relationship with her, and this becomes a reality, when the translator allays his fear of taking Waterman's place: "Ne t'inquiète pas, dit-elle. Je me suis entendue avec lui” (Poulin, 2009, p. 114). But little does it matter who does the replacing, the writer is well and truly replaced, and the "underling" (in this case, the brother, not the translator) rises in status: "À la fin, je n'étais 
pas sûr d'être encore un petit frère" (ibid., p. 146), remarks Francis, on the verge of relinquishing his self-imposed nickname, after making love with Marine for the first time. Poulin does not divulge the impact of this new relationship on the pre-existing one between Waterman and Marine, nor does he develop the impression that, in the final chapter focusing on Francis and Limoilou, the younger brother also seems to replace Waterman as Limoilou's foster father, bringing her to discuss literature in the same park-like cemetery where the writer and translator met for the first time. ${ }^{14}$

Despite Marine's desire for independence and the very real decline in Waterman's health and ability to write, writer and translator in this novel share many similarities in the way they work and in their relationships with words, making them as much mirror images of one another as their texts may be. It is in the notion of relationships with words that the plot device of the lost kitten is used to display this concretely. Briefly put, at the isolated cottage, Marine finds an abandoned kitten with a note folded into its collar: "Je m'appelle famine. Je suis sur la route parce que ma maitresse ne peut plus s'occuper de moi..... ..” (Poulin, 2006, p. 36, italics and long ellipsis in original). The author-translator duo is worried about why the cat's mistress is unable to look after it, and hope that if they discover the missing words at the end of the note they will learn the details of the story, and offer help if it is needed. Though wondering however if, for some unknown reason "[ils] ont été effacés volontairement” (ibid., p. 39), they do succeed in revealing the missing words, by heating the paper in a way Marine read about in an old adventure novel. This trick allows them to read the final words "ni d'elle-même" (ibid., p. 40) — allowing them to understand that the cat's owner cannot take care of it or herself-but the match used to heat the paper sets the note on fire and the first half of the message is lost - the

\footnotetext{
${ }^{14}$ For an examination of romantic relationships in Poulin's writing, particularly in La Tournée d'automne, see Lori Saint-Martin (1999).
} 
original text and its completion are never visible on the page at the same time-one half or the other is always missing. Together, all the words, and some detective work, do lead Marine and monsieur Waterman to the owner of the kitten, but not until she has attempted suicide. Following her hospitalization, she agrees to go and live with Marine at the cottage-with visits from Waterman on the weekends - to recuperate, and be reunited with her kitten.

Though in this instance they found the words together, when they are working- be it writing or translating-Waterman and Marine often struggle to find words. Marine sometimes comments on this, saying things like, "tout à l'heure les mots ne venaient pas" (ibid., p. 63), and describes the author as being blocked nearly as soon as he begins to write: "à peine avait-il commencé à travailler qu'un mot lui faisait défaut” (ibid., p. 52). Waterman is most often described as pacing and thinking until the illusive idea, word, or phrase is grasped, and Martine sometimes walks, but she also swims and pulls algae out of the pond or talks to the retired race horses or willow trees. Similar struggles, with release sought in physical activities are also present in the author and translator characters in Les Grandes marées, confirming the central role they play in the work of translators and writers both. In each case, Poulin describes the situation as if the words were some elusive butterflies fluttering just out of reach of the one whose means of expression depends on them, showing ultimately that the only real solution is patience and a willingness to wait until the seemingly autonomous words are ready to appear.

While authors and translators in Poulin's novels share the common difficulty of searching for the perfect word, the translators have the added constraint of producing a text that somehow lives up to its original, and dictionaries are often proved inadequate in providing the necessary word-leaving the real work of translation to the instinct and understanding of the translator, which doesn't always agree with the accepted usage, or the exact word used in the source text, as shown above. One strategy Marine uses to succeed is to put herself in Waterman's place by adopting his writing habits: "je traduisais deux courts chapitres du texte de monsieur Waterman, très lentement parce que c'était de cette façon que lui-même travaillait" (ibid., p. 42). When this 
method is insufficient, "[1]es jours où [elle] n’y arrive pas, [Marine] emprunte les vêtements que monsieur Waterman laisse au chalet. [... C'est une habitude un peu Zouave, mais elle [lui] donne [à elle] le sentiment d'être plus proche de lui et de son écriture” (ibid., p. 42). Additionally, while trying to assert her personal and linguistic independence as we've seen, Marine also in some ways seems to seek out the traditional, metaphoric role of spouse to the writing, if not to the writer, using this comparison at least twice: “On fait un drôle de travail, nous les traducteurs. N'allez pas croire qu'il nous suffit de trouver les mots et les phrases qui correspondent le mieux au texte de départ. Il faut aller plus loin, se couler dans l'écriture de l'autre comme un chat se love dans un panier. On doit épouser le style de l'auteur" (ibid., p. 41, italics in original). In fact, Marine has read and safeguarded her copy of Kafka's Lettres à Milena through her years of travels and moving, reminding her of a translation course, in which she remains unsure if it was Milena herself or the professor who really said "Chaque jour pour être fidèle à votre texte, mes mots épousent les courbes de votre écriture, à la manière d'une amante qui se blottit dans les bras de son amoureux" (ibid., p. 113). And while on the personal level she claims she does not want to be-and ultimately proves not to be - anyone's faithful compagnon-what she perceives as fidelity in translation proper is a preoccupation for her: "Dans le chapitre que je traduisais, qui était le dernier, monsieur Waterman avait enlevé tous les mots inutiles, il avait soigné la ponctuation, et j'essayais de lui être fidèle. Comme Milena, je voulais que mes mots épousent les courbes de son écriture" (ibid., p. 131, our italics). As Marine seems to apply two rules in her relationships - one for herself as a person and one for her translated text with Waterman and his text - the influence of the translating relationship on the personal relationship remains unclear. In other words, is it possible that it is the translator's obligations to the text lead the individual to insist so heavily on her personal freedom and eventually choose another sexual and romantic partner for herself?

Ultimately, as seen in the teamwork used to complete the mysterious note, to find the kitten's owner, and to offer a safe home to Limoilou, symbiosis and a non-hierarchical 
relationship seem to be the paradigm for a successful relationship between author and translator, as both have the occasion to supply words to the other. While Marine writes letters to Waterman with the specific purpose of supplying him not only with news but more importantly with envelopes upon which to scribble the words that finally make themselves known, ${ }^{15}$ in the hospital, when the characters are inviting Limoilou to live at the cottage, Marine needs Waterman to complete her sentences when she can't find her words. ${ }^{16}$ Before they even arrive at the hospital, she admits it will take both of them to convince the teenager of their plan, hoping that "peut-être à nous deux, on aurait des chances de trouver les mots justes" (ibid., p. 119). The connection between the two individuals can perhaps be traced to their shared interest in the Oregon trail and the settling of the American west. Indeed, Marine's physical reaction to visiting the trail while hitchhiking across the US is simalr to the one she has when she first shows Waterman her translation, finding that “[s]on coeur à [elle] s'est mis à battre plus fort, du seul fait qu'[elle] marchai[t] dans [les] traces [des pionniers]" (ibid., p. 18). This scene is foreshadowing of the relationship between translator and author/text, as one which the translator follows in the steps of the poet. It is specifically described by French poet, translator and critic Claude Esteban who reflects on his choices and his need to translate in an essay entitled "Traduire" in the collection Critique de la raison poétique. For him, there is something soothing and somehow comforting in translating a text that we connect deeply with, even if we don't know why we have this connection; he writes, “comprendre aurait dû me suffire, si je n'avais présenti que la route semble moins incertaine lorqu'aux heures de plus haute alarme, pour se retrouver, parfois pour se perdre, on met ses pas dans les pas d'autrui" (Esteban, 1987, p. 180). Following in the steps of one who's

\footnotetext{
15 “Et quand il avait trouvé, il s'asseyait à cette table pour griffonner quelques mots sur une des enveloppes de son courrier. Étant au fait de cette manie, je lui envoyais des lettres afin qu'il ne manque jamais de quoi écrire” (Poulin,
} 2006, p. 38).

${ }^{16}$ Marine speaks to Limoilou “avec l'aide de monsieur Waterman qui complétait [ses] phrases” (Poulin, 2006, p. 121). 
come before is neither subservient nor superior, it is simply later in time, yet the fact of travelling the same path allows for very necessary connection on a human level. As Esteban wrote, when we are following in another's footsteps, we don't feel quite so alone on our own path.

Poulin's and Matthieussent's novels challenge the apparent simplicity of the authortranslator relationship by humanizing these figures and thereby contribute to establishing a poetics of translation. The title of each novel evokes extremely different relationships between author and translator - one is openly vengeful, the other seems to be something out of a fairy tale-yet both novels prove in very dissimilar ways, in very different universes, that the relationship between author and translator, like the one between source and target text, is never as simply binary as these two pairs would lead us to believe.

Their relationship is complementary, yet oftentimes competitive, as we have seen. This complexity is perhaps better understood through the explicit references found in both books to Kafka's Letters to Milena. Whilst on the one hand, Marine compares herself to Milena and wants her words to "épousent les courbes de son [the author's] écriture" (Poulin, 2006, p. 131), as already discussed above, Matthieussent opens his book with the following quote: "moi qui ne suis même pas sur le grand échiquier le pion d'un pion—une figure qui n'existe même pas, qui ne participe même pas au jeu -, je veux, prendre la place de la reine, peut-être même la place du roi en personne, si ce n'est de tout l'échiquier..." and shows the interchangeable nature of their relative functions, from powerless pawn who cannot access the game's higher level of consciousness to the powerful queen and even king. In other words, Vengeance $d u$ traducteur and La Traduction est une histoire d'amour both attempt to break out of binary, power-based understandings of translation in a way that invites us rather to read in them, Derrida's notion, according to Chamberlain, that "translation is both original and secondary, uncontaminated and transgressed or transgressive. [...] By arguing the interdependence of writing and translating, Derrida subverts the autonomy and privilege of the 'original' text, binding it to an impossible but 
necessary contract with the translation and making each the debtor of the other" (Chamberlain, 1988, pp. 469-470).

\section{References}

BALAZUC, Olivier (2010). Le Labyrinthe du traducteur. Paris, Belles Lettres.

BARTHES, Roland (1984). "La mort de l'auteur.” In R. Barthes, ed., Le Bruissement de la langue (Essais critiques 4). Paris, Seuil, pp. 63-9.

BLETON, Claude (2008). Les Nègres du traducteur. Paris, Métailié.

BONSIGNORE, Giacomo (1985). “Jacques Poulin: une conception de l'écriture.” Études françaises, 21, 3, pp. 19-26.

BOURSE, Anne (2010). “Quand le traducteur se rebiffe.” Acta fabula, 11, 10. Available online: http://www.fabula.org/revue/document6025.php [accessed 9 August 2017].

BROSSARD, Nicole (1987) Le désert mauve. Montréal, L'Hexagone.

CHAMBERLAIN, Lori (1988). “Gender and the Metaphorics of Translation.” Signs, 13, 3, pp. 454-72.

CONSTANTINESCU, Muguras (2009). "Pour une poétique de la traduction.” Acta Fabula, 10,

5. Available online: http://www.fabula.org/revue/document5049.php [accessed 9 August 2017].

COPPOLA, Sofia (2003). Lost in Translation. Focus Features.

CRONIN, Michael (2008). Translation Goes to the Movies. London, Routledge.

DELABASTITA, Dirk and Rainier GRUTMAN, eds. (2005). Fictionalising Translation and Multilingualism, Linguistica Antverpiensia 4.

DELEUZE, Gilles and Félix Guattari (1981). Mille Plateaux. Paris, Minuit.

ESTEBAN, Claude (1987). Critique de la raison poétique. Paris, Flammarion.

FOSSET, Jean-Paul (2008). Le Traducteur perd le Nord. Roubaix, Riffle. 
FOUCAULT, Michel (1969). “Qu'est-ce qu'un auteur?” In M. Foucault et al., eds., Dits et écrits I, 1954-88. Paris, Gallimard, pp. 789-821.

FÜLÖP, Erika (2014). “Born in Translation: The Self Which Is Not One in Brice Matthieussent's Vengeance du traducteur.” In E. Fülöp and A. Angelo, eds., Protean Selves: first-person voices in twenty-first century French and Francophone narratives. Newcastle Upon Tyne, Cambridge Scholars, pp. 54-66.

GAVRONSKY, Serge (1977). “The Translator: From Piety to Cannibalism.” Sub-stance, 16, pp. 53-62.

GELAT, Jacques (2010). Le Traducteur amoureux. Paris, Corti.

GENETTE, Gérard (1987). Seuils. Paris, Seuil.

GODBOUT, Patricia. (2010). "Le traducteur fictif dans la litérature québécoise: notes et réflexions. Cahiers franco-canadiens de l'Ouest, La traduction à l'ère de la mondialisation, 22, 2, pp. 163-175. Available online: https://www.erudit.org/fr/revues/cfco/2010-v22-n2-cfco093/1009121ar/ [accessed 15 October 2017].

HOFFMAN, Eva (1990). Lost in Translation: life in a new language. London, Penguin.

KAINDL, Klaus (2014). “Going fictional! Translators and interpreters in literature and film: an introduction." In K. Kaindl and K. Spitzl, eds., Transfiction: research into the realities of translation fiction. Amsterdam/Philadelphia, John Benjamins, pp. 1-26.

KAINDL, Klaus and Karlheinz SPITZL, eds. (2014). Transfiction: research into the realities of translation fiction. Amsterdam/Philadelphia, John Benjamins.

MATTHIEUSSENT, Brice (2009). Vengeance du traducteur. Paris, P.O.L.

MAUSSION, Claire (2013). "Notes du Traître: figures du critique et du traducteur dans le roman contemporain.” Les Cahiers de Ceracc, 6, July 2013. Available online: http://www.cahiers-ceracc.fr/maussion.html [accessed 9 August 2017]. MESCHONNIC, Henri (1999). Poétique du traduire. Paris, Verdier. 
PLASSARD, Freddie (2010). "Mineur de fond ou chirurgien esthétique? Traducteur et traduction dans Vengeance du traducteur de Brice Matthieussent." Translationes, 2, pp. $55-65$.

POULIN, Jacques (1978). Les Grandes marées. Montreal, Leméac.

POULIN, Jacques (1998). Volkswagen Blues. Montreal, Leméac/Actes Sud.

POULIN, Jacques (2006). La Traduction est une histoire d'amour. Montreal, Leméac.

POULIN, Jacques (2009). L'Anglais n'est pas une langue magique. Montreal, Leméac.

RÉE, Jonathan (2001). “The Translation of Philosophy.” New Literary History, 32, 2, pp. 223 57.

RICEUR, Paul (2004). Sur la traduction. Paris, Bayard.

SAINT-MARTIN, Lori (1999). “L'androgynie, la peur de l'autre et les impasses de l'amour: La tournée d'automne de Jacques Poulin.” Études françaises, 24, 3, pp. 541-557.

SIMEONI, Daniel (2004). "Le traducteur, personnage de fiction.” Spirale, 197, pp. 24-5.

VENUTI, Lawrence (1995). The Translator's Invisibility: A History of Translation. London, Routledge.

WECKSTEEN, Corinne (2013). "Le traducteur: un écrivain refoulé? Réflexions sur Les Nègres du traducteur, de Claude Bleton, et sur Vengeance du traducteur, de Brice Matthieussent.” Parallèles, 25, pp. 51-64. Available online: http://www.paralleles.unige.ch/tous-les-numeros/numero25/wecksteen/Wecksteen_Paralleles_25_pp51-64.pdf [accessed 9 August 2017]. 